\title{
Palynofacies, palaeoenvironments and petroleum
}

\author{
D. J. BATTEN \\ Department of Geology and Mineralogy, Marischal College, Aberdeen University, Aberdeen AB9 1AS, Scotland
}

\begin{abstract}
During the past decade, transmitted light microscopy of dispersed organic particles has become an important tool for assessing the petroleum potential of sedimentary basins. The main components of palynofacies and the colours of the microfossils preserved therein are widely used in the oil industry to aid the determination of organic maturation level and source rock potential for hydrocarbons. Less well known is the technique of integrating palynofacies and sedimentological data to facilitate the identification of depositional environments. While not a new development in the field of palynology, the subject has recently come of age. Selected palynofacies from the English Wealden (Lower Cretaceous) and elsewhere are briefly described and illustrated in order to emphasise the value of palynofacies studies to both palynologists and petroleum geologists.
\end{abstract}

\section{INTRODUCTION}

Gone are the days when palynology meant solely the study of spores and pollen. It now encompasses investigations on all kinds of microscopic organic particles (phytoclasts; Bostick, 1971) ranging from entities with well defined morphology, such as dinoflagellate cysts and chitinozoans, to fragments of wood and cuticle, structured and unstructured algal remains, and tissues of uncertain origin which are less easy to categorise. The biostratigraphic application of palynomorphs (plant microfossils) continues to be the most important area of activity for the majority of professional pre-Quaternary palynologists. During the past decade, however, increased attention has been paid to the wide variation in composition of organic facies associated with different rock types and has led to a rapid expansion of research in other non-biostratigraphic fields of endeavour.

The most important of these, because of its value to the oil industry, is currently the determination of petroleum source potential from the amount, composition and colour of organic matter recovered from sedimentary rocks. Palynofacies studies (sensu Combaz, 1964) are also useful to the petroleum geologist because they can contribute to the identification of depositional environments, thus aiding the general evaluation of the hydrocarbon potential of a sedimentary basin. Although there is literature on the integration of palynological and sedimentological data extending back to the late 1950's, only within the last few years has a significant number of specialists in these fields taken this sort of work seriously. Of more academic significance is the application of palynofacies associations to terrestrial palaeoecology, palaeophytogeography and palaeoclimatology. To accomplish anything of value a palynologist must delve into a vast and ever expanding literature in a variety of geological and non-geological disciplines.
Selected examples of palynofacies are briefly discussed and illustrated herein. Relationships to depositional environment and source potential for petroleum are considered. Most of the descriptive words used are well known to palynologists and organic petrographers, but equivalent terms or author citations accompany some in parentheses where clarification is considered necessary. The word "kerogen" has been variously defined; it is used here only in a palynological sense to mean disseminated sedimentary organic matter that is insoluble in non-oxidizing acids (palynological kerogen in Cope, 1981).

\section{PALYNOFACIES ANALYSIS}

Projects on source potential and maturation have been, for me, a natural extension of earlier palynofacies studies on the English Wealden (Lower Cretaceous), first begun in 1966 (Batten, 1968, 1969, 1973a, b, 1974). At that time, there was very little literature on the palaeoenvironmental significance of the distribution of palynomorphs and other plant remains in sedimentary rocks. Recurrent associations of a few taxa had been recognised (e.g. in Hughes \& Moody-Stuart, 1967) and there was some appreciation of the variations in phytoclast assemblages in Recent sediments (e.g. Muller, 1959), but there were no papers on the entire acid resistant organic content of sedimentary rocks and the concept of palynofacies had only just been formulated (Combaz, 1964).

Despite having its origins in the late 1950's, to judge from the published record, research on palynofacies has formed little or no part of the studies of the majority of palynologists. Only recently has the subject attracted more attention (e.g. Habib, 1979; Denison \& Fowler, 1980; Hancock \& Fisher, 1981; Parry et al., 1981). 
There is no doubt that advances can be made into the realm of palaeoenvironmental interpretation using phytoclasts provided that 1) sampling programmes are sufficently detailed, 2) as many sedimentological and palynological parameters as possible are taken into account, and 3) standard laboratory processing techniques are used (Batten \& Morrison, in press). Relationships between various aspects of organic preparations and sedimentary environments can certainly be determined. Quantitative techniques in which a computer is used to facilitate data handling may help to consolidate the basis on which palynofacies are identified (Batten, 1973a). If large numbers of samples are not examined, and certain associations have not been registered for at least several samples from different localities, then the chances of drawing incorrect conclusions are greatly increased.

Much of my early work on Wealden material was concentrated on determining whether it was possible to identify associations between plant microfossils and other organic particles, and on attempting to correlate many palynofacies characters with lithofacies and depositional environments. Numerous significant relationships were recognised, some of which were used to draw various palaeoenvironmental conclusions (Batten, 1969, 1973b, 1974). However, while a combination of palynological and sedimentological data formed the basis of assessment of depositional conditions (e.g. in Batten, 1974, pp. 448-452), interpretations were hampered to some extent by uncertainties concerning the sedimentological models which had been proposed to account for the overall composition of the Wealden succession (Allen, 1959, 1967). Recent detailed sedimentological and palynofacies analyses have, however, enabled further advances to be made (Allen, 1975, 1981; Stewart, 1981a, b; Batten \& Eaton, 1980; Batten, in press). Many new relationships have been recognised and are being used to aid the interpretation of depositional environments, the structure of the terrestrial vegetation, and the climate. For economy of space, consideration is here given merely to the general aspect and depositional associations of a few selected palynofacies, adding to those illustrated in Batten (in press). Some examples of palynofacies from elsewhere are also briefly discussed.

Wealden Palynofacies. Wide variations and rapid changes of lithology are typical of sediments which were deposited in fluvial, estuarine and deltaic environments. As would be expected, the composition of the organic matter preserved in such successions is also very variable. While palynofacies analyses of marine rocks are no less important, investigations into the distribution of phytoclasts in strata which represent fluvial and paralic accumulations are, perhaps, generally more rewarding because the lithological changes tend to be accompanied by a greater diversity of organic facies, including those which indicate fluctuating salinity. The lithologically varied, essentially non-marine Wealden succession is thus ideally suited to combined sedimentological and palynological analysis aimed at palaeoenvironmental interpretation (Sladen \& Batten, in preparation).

\section{Explanation of Plate 1}

Stage co-ordinates refer to Leitz Dialux microscope, no. 322m Department of Geology and Mineralogy, Aberdeen University.

All magnifications x 150 .

Fig. 1. Palynofacies from an abandoned channel-fill deposit dominated by land plant ("humic") debris, miospores well preserved. Sample DJB/CE 29, a grey siltstone containing megascopic plant fragments from Goldbury Point. near Hastings, Sussex; Ashdown Beds, probably upper Berriasian. Preparation MCP 621.2, 26.5 123.0

Fig. 2. Comminuted plant debris dominates overbank mudstone palynofacies; fungal remains relatively common, palynomorphs generally well preserved. Sample DJB/CE 32(ii), a medium grey mudstone containing gymnospermous plant fragments from the vicinity of Goldbury Point as above. Preparation MCP 625.2, 25.1 127.8.

Fig. 3. Gymnosperm pollen grains, particularly bisaceates and Classopollis, dominate a possible lagoonal palynofacies. Sample DJB/CE 7, a light brownish-grey silty mudstone from Cliff End, near Hastings, Sussex; lower Wadhurst Clay, Valanginian. Preparation MCP 515.2, 27.9 125.6.

Fig. 4. Possible lacustrine palynofacies containing abundant but generally rather degraded miospores, numerous Botryococcus and some Schizosporis. Sample DJB/CE 5, a laminated siltstone from Cliff End as above; upper Ashdown Beds, Valanginian. Preparation MCP 513.2 33.6 129.3.

Fig. 5. Inertinite and degraded miospores dominate this palynofacies which also contains Botryococcus. Sample DJB/ CE 1, comprising siltstone and mudstone laminae from a possible lacustrine deposit, Cliff End as above; upper Ashdown Beds, Valanginian. Preparation MCP 510.2, 46.7 121.0.

Fig. 6. Weald Clay palynofacies dominated by an as yet undescribed dinoflagellate cyst, recovered from a calcareous lacustrine mudstone, IGS Ripe Borehole, depth 170.5-171 m, Barremian. Preparation MCP 1083.1, 26.2 126.1. 


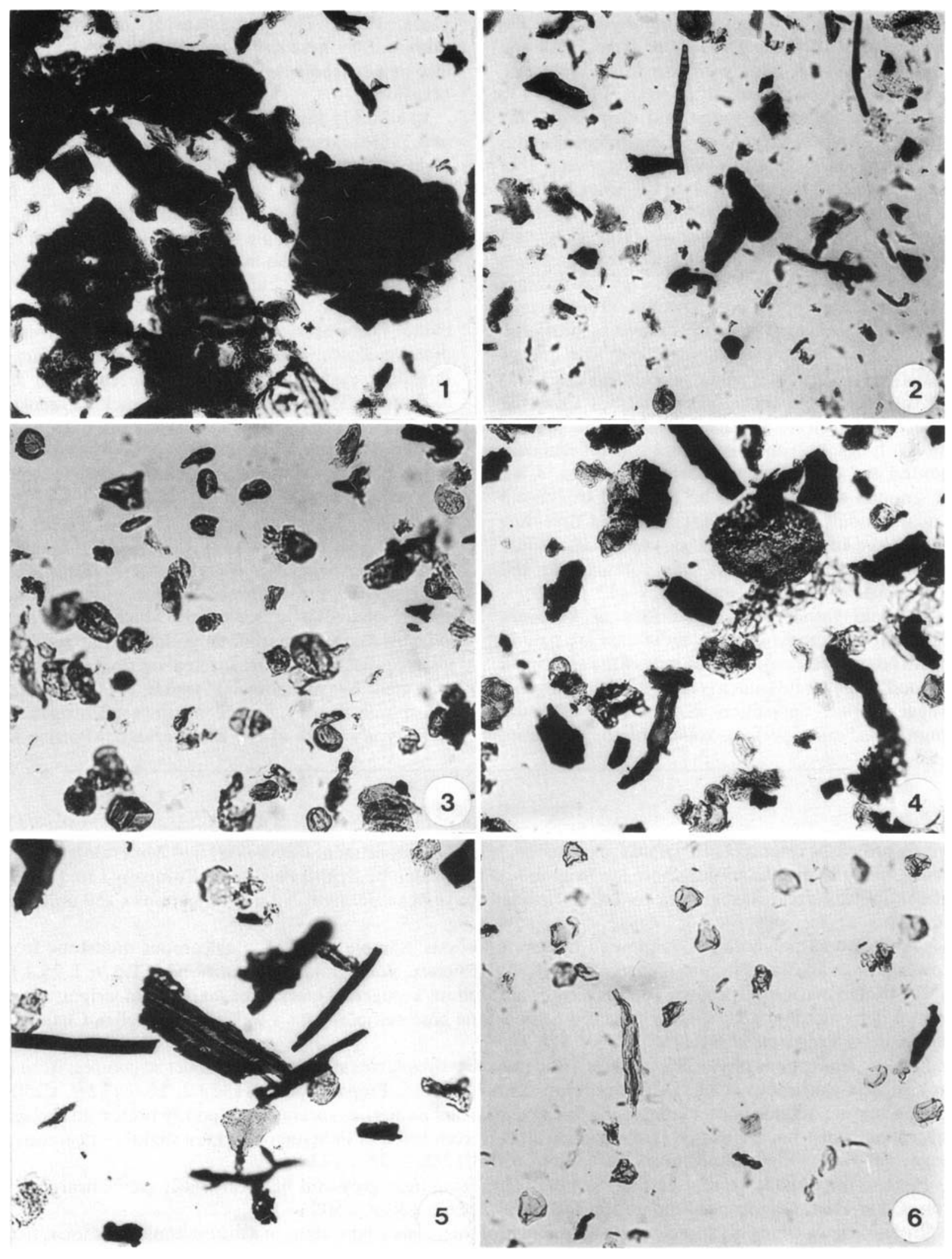


Wealden palynofacies have been related to, and used to determine, depositional environments on both a mega- (formation) and micro- (bed-by-bed) scale. Among the most distinctive are those from Wadhurst Clay subaqueous soil beds with the fossil 'horsetail' Equisetites in position of growth (Batten, 1968, 1973b and in press). Certain Wadhurst and Grinstead Clay mudstones are rich in Celyphus and cheirolepidiaceous pollen (Classopollis; Batten, 1973a), suggesting that deposition occurred in fresh to brackish water lagoons. Some abandoned channel-fill silts and distal parts of silty crevasse splays in the Ashdown Beds yield vast numbers of well preserved miospores and megaspores (Batten, 1969 and in press). High energy distributary channel sands and point bars contain little organic matter; what is recovered is mostly classed as inertinite. Between the two extremes of high and low energy accumulations a variety of other palynofacies has also been identified. These include preparations from the Ashdown Beds which are dominated by comminuted plant detritus (Pl. 1, figs. 1,2) and some which contain abundant fragmented and degraded miospores (Pl. 1, figs. 3, 4).

Fine grained sediments can be expected to contain large quantities of organic matter, provided that they were deposited in essentially anoxic conditions. While organic-rich argillaceous beds are common in the Wealden succession, many mudstones and siltstones, however, yield rather small quantities of kerogen. Typically, the miospores in these sediments are pale in colour and poorly preserved, and the bulk of the associated black 'wood' is inertinite (Stach et al., 1975; Pl. 1, fig. 5); this suggests that deposition occurred in oxidising environments. Some, perhaps much, of the inertinite could be the product of fire (Batten, 1974, 1981 and in press; see also Harris, 1958; Scott $\&$ Collinson, 1978; Cope, 1981). The poor state of preservation of the miospores in these and many other Wealden facies might also be a consequence of local reworking on one or more occasions.

In addition to variations in the character of the spore and pollen assemblages, parts of the succession also yield assemblages of dinoflagellate cysts. As explained elsewhere (Batten, in press) quite a few are clearly reworked from older (Jurassic) strata. Of the forms which are in situ, some are identified as marine species and occur in brackish-marine facies. Others are referable to marine genera but cannot be identified with any known species; these probably reflect brackish environments. Several may well be the cysts of freshwater dinoflagellates. Hitherto, almost all pre-Tertiary dinoflagellate cysts have been considered to be marine indicators. The various fresh to brackish associations which have been recognised so far differ from typical marine Cretaceous assemblages in being taxonomically impoverished, though individual species may be numerically important (Pl. 1, fig. 6, Pl. 2, fig. 1).

Selected palynofacies from elsewhere. 'Clean' preparations containing diverse fossil dinoflagellate assemblages and miospore associations of limited variety characterise sediments which were deposited in open marine environments during the Jurassic and Cretaceous Periods. Restricted marine conditions are indicated by palynofacies which are dominated by amorphous matter. In the northwest European area, these typify much of the Kimmeridgian-Portlandian of

\section{Explanation of Plate 2}

Stage co-ordinates refer to Leitz Dialux microscope, no. 322, Department of Geology and Mineralogy, Aberdeen University. Some of the illustrations here are from samples provided by British Petroleum Company Ltd. For reasons of confidentiality, certain stratigraphic and locality details have been omitted. All magnifications $x 150$ unless otherwise stated.

Fig. 1. A ?lagoonal palynofacies dominated by ceratioid cysts. Sample DJB/P3, a calcareous mudstone from the Lower Grinstead Clay, Philpots Quarry, West Hoathly, Sussex, Valanginian. Preparation MCP 676.2, 25.4 124.3.

Fig. 2. Restricted marine palynofacies dominated by amorphous kerogen of marine, probable algal, origin; recovered from a light-medium grey slightly calcareous mudstone core sample from a well in the English Channel area, Portlandian. Preparation DB1 198.2, 36.1 124.3.

Fig. 3. Flakey amorphous phytoclast in a restricted marine palynofacies showing pyrite relict structures; from a dark grey slightly calcareous shale, Dorset outcrop, Kimmeridgian. Preparation DB 1323.2, 28.6132 .9 , x 250.

Fig. 4. Non-marine organic matter comprising flimsy tissues and numerous specimens of poorly preserved Pediastrum, suggesting lacustrine deposition; from a sidewall core composed of light-medium grey slightly calcareous mudstone, Far East, Oligocene/Miocene. Preparation DB 1288.2, 33.2 123.8.

Fig. 5. Pediastrum isolated from a cuttings sample comprising light grey and light brownish grey calcareous mudstones, Far East, Oligocene. Preparation DB 1260.2, 28.6130 .9 , x 500.

Fig. 6. Probable lacustrine palynofacies with abundant Botryococcus-type algac in a different plane of focus from the rest of the organic matter; recovered from a cuttings sample consisting of light-medium grey and medium grey shales, North Sea, Jurassic. Preparation DB 1158.3, 39.4 125.8. 


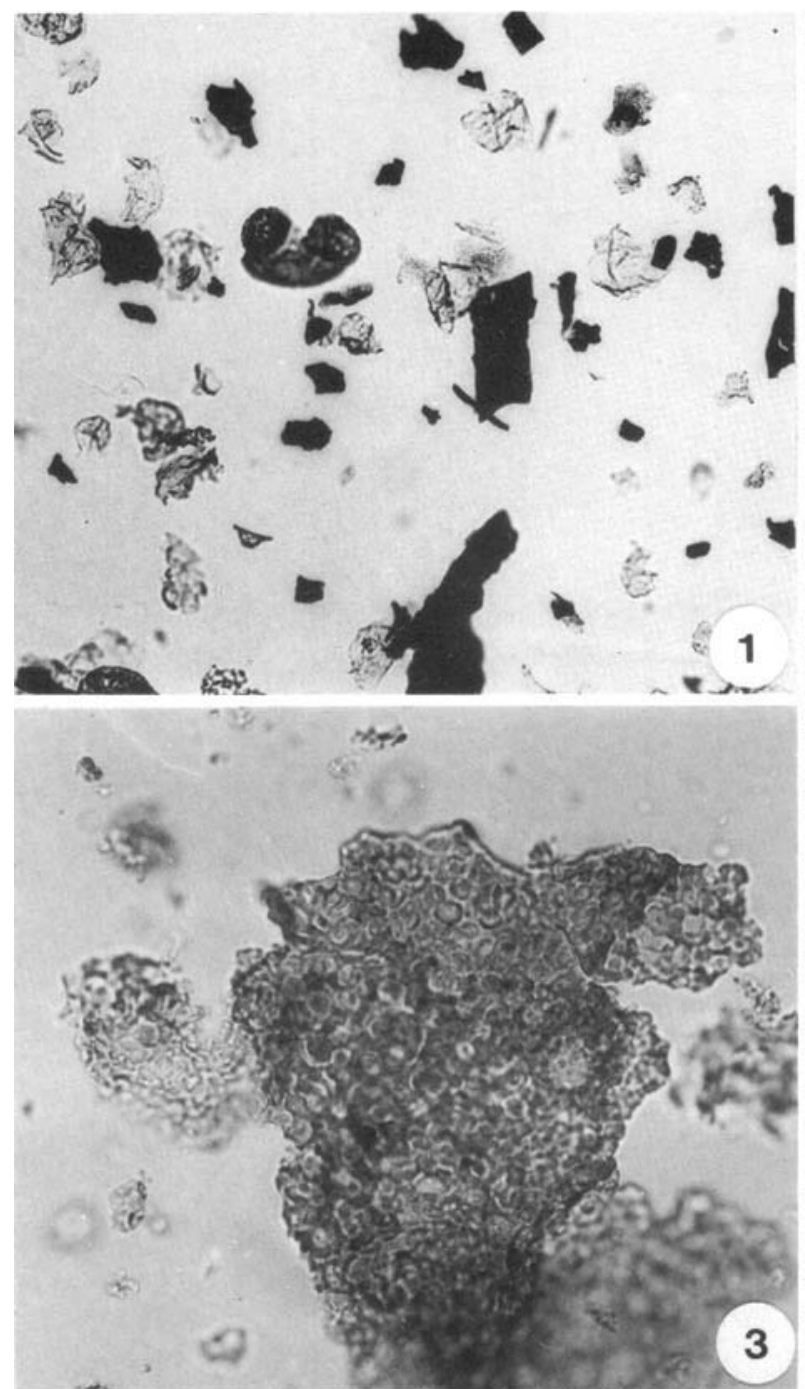

The S.

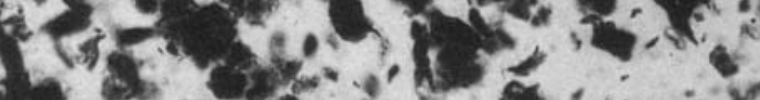

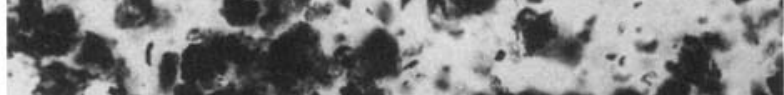
3. 2 .

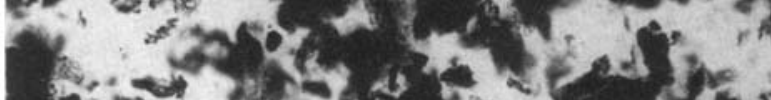

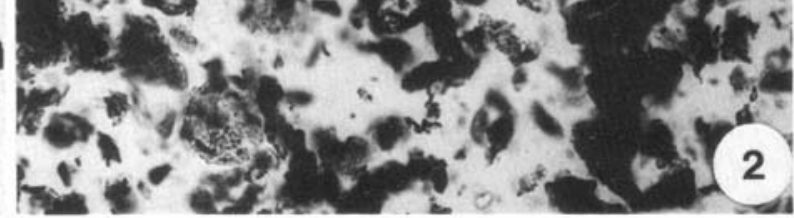

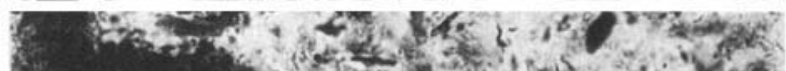

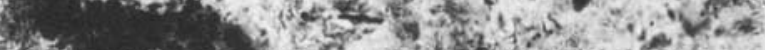

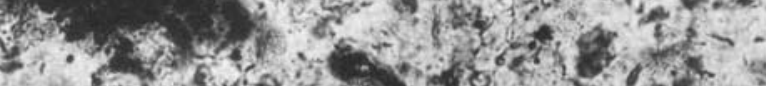

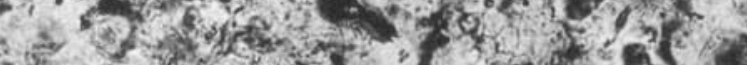

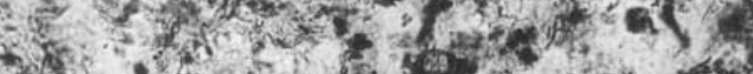

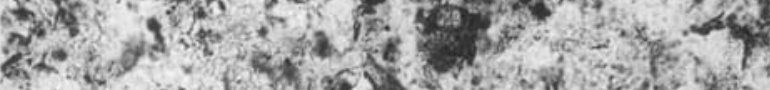

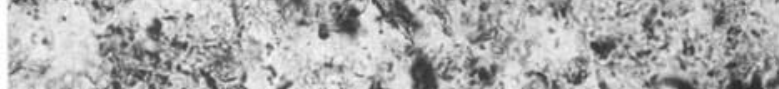

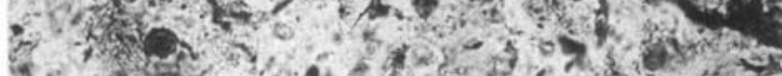

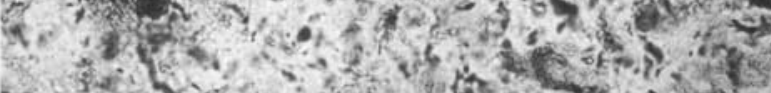

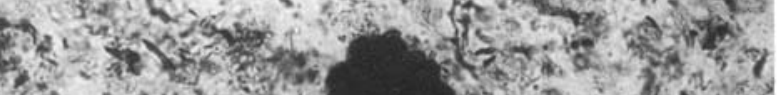
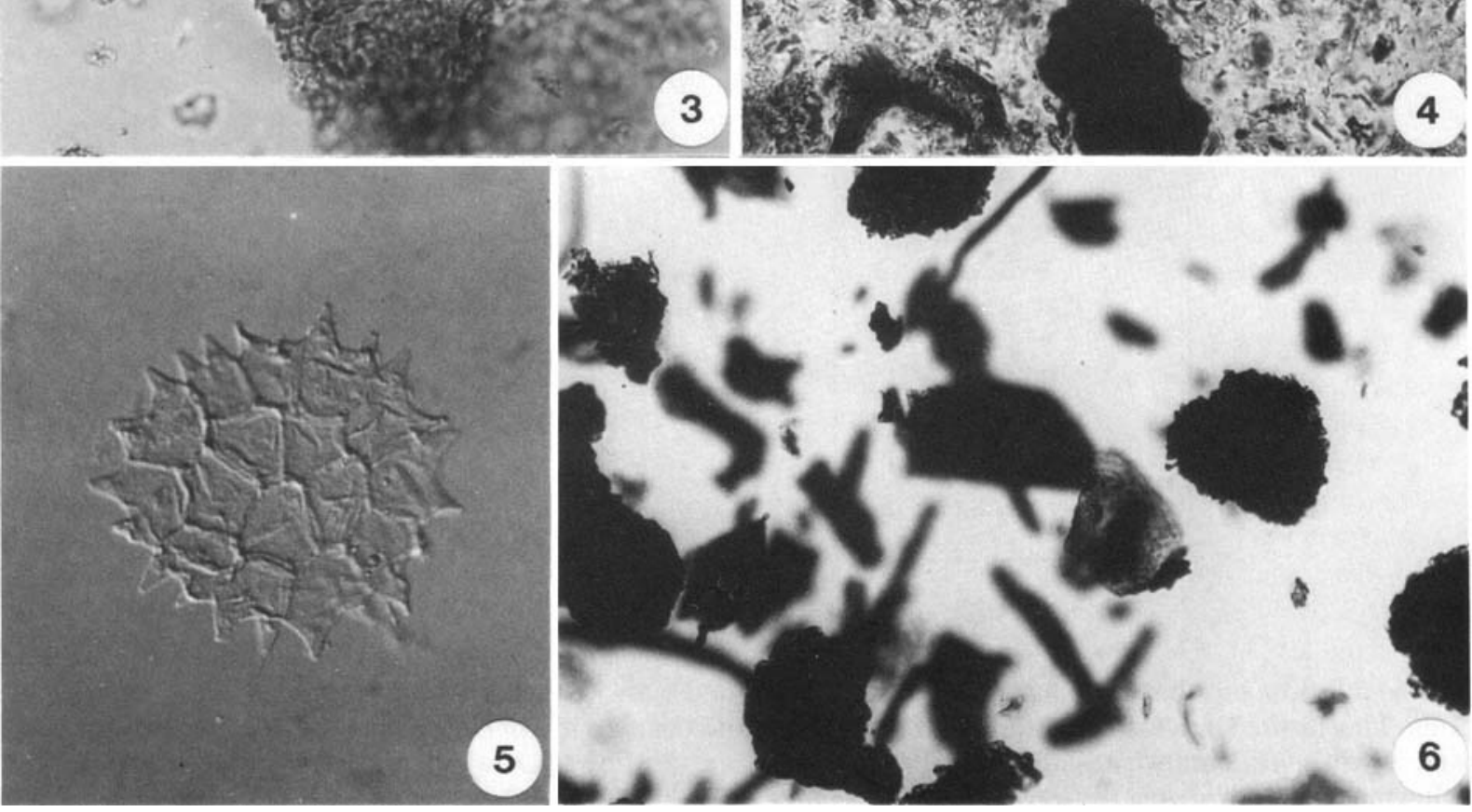


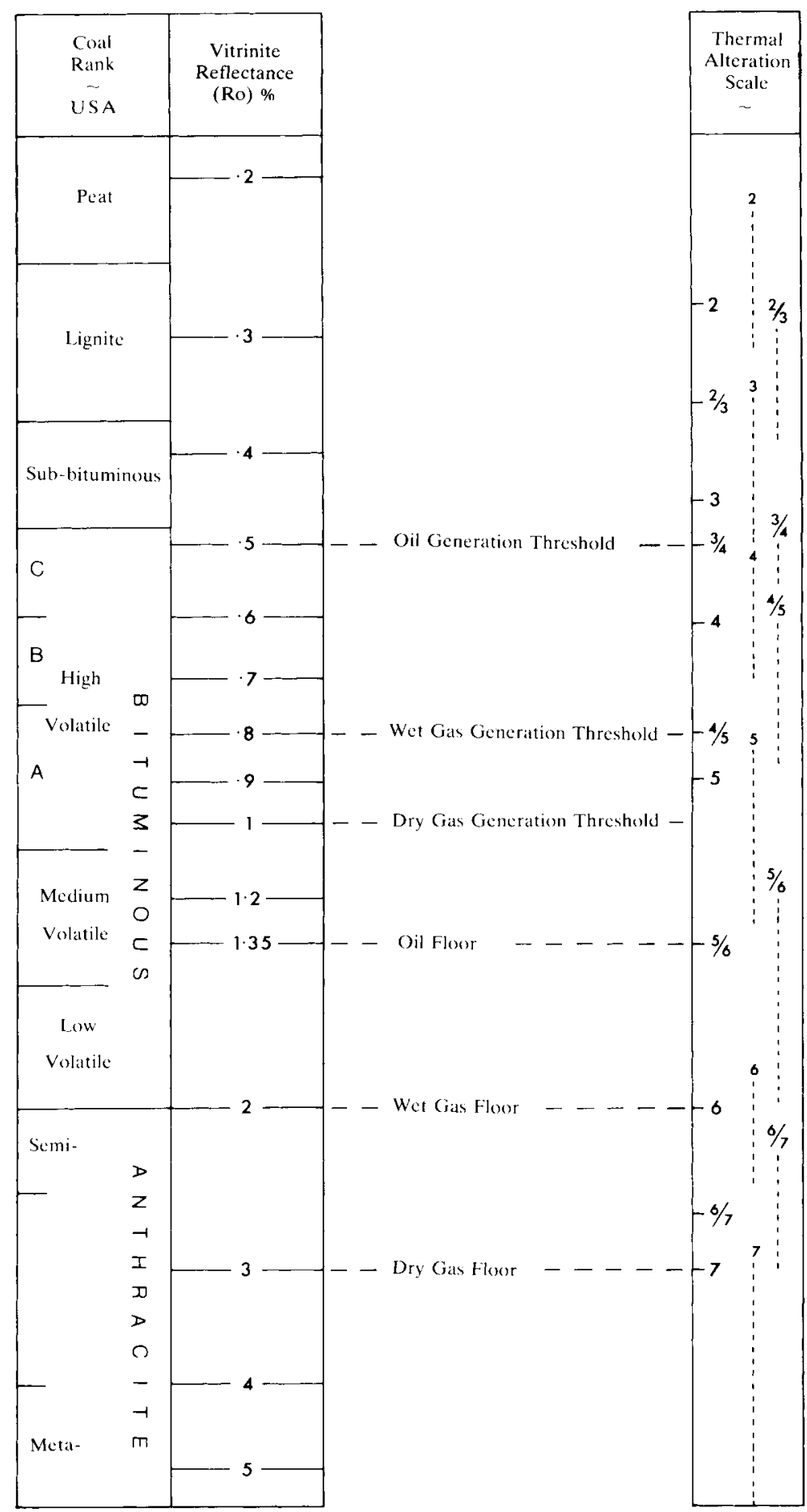

Fig. 1. The relationships between maturation parameters and hydrocarbon products are subject to varying interpretations. This figure shows the thresholds of generation and destruction of oil and gas tentatively correlated with coal rank, vitrinite reflectance and thermal alteration scales according to Dow (1977) and Batten (1981). Reference to a thermal alteration scale (TAS) rather than an index (TAI in Batten, 1981) is now preferred in order to avoid any possible confusion with the indices of Staplin (1977), Dow (1977) and others. Dashed lines to the right of the scale indicate the normal limits of operational error in transmitted light assessments of palynomorph colours. 
the North Sea and some of the upper Cenomanian and Turonian of northern Germany (Batten, 1978, 1981). Restricted water circulation rather than productivity (Tyson et al., 1979) may have been the chief factor which controlled the accumulation of these organic-rich sediments. The resulting anoxic conditions inhibited microbial activity and led to the sedimentation of large quantities of only partly degraded organic matter.

Most of the amorphous kerogen in the north German and North Sea sections is thought to be algal in origin. It is generally rather granular in appearance but may be fairly massive or flakey, and commonly bears relict structures of pyrite (Batten, 1981, Pl. 3, figs. 1-4; Pl. 2, figs. 2, 3 herein). Pyrite can be produced by inorganic precipitation but is typically associated with the activities of sulphate reducing bacteria. Tasmanitids, leiospheres and foraminiferal linings are often comparatively numerous in marine palynofacies dominated by amorphous matter.

Amorphous kerogen recovered from non-marine Jurassic and Cretaceous sediments tends not to have the same appearance as the restricted marine type. It is usually more fibrous (Batten, in press) and seldom clearly of algal origin; this is difficult to separate from other unstructured substances derived from land plants. Botryococcus s.l. and, in the Tertiary, Pediastrum (PI. 2, figs. 4,5 ) may occur in large numbers in palynofacies dominated by non-marine amorphous debris.

\section{PETROLEUM SOURCE POTENTIAL}

When abundant, both Botryococcus (Pl. 2, fig. 6) and amorphous matter of marine/algal origin (referable to kerogen types I and II in Tissot \& Welte, 1978) suggest good source rocks for oil. Palynological preparations dominated by land plant detritus tend to suggest potential for gas. It is partly because such conclusions can be drawn from light microscope analysis of organic facies that there has been a surge of interest during the past decade in determining the precise relationships between the physical properties of dispersed kerogen and petroleum generation. It is also due to the fact that the changes in colour of particulate organic matter (especially miospores) reflect rather accurately the degree to which sedimentary rocks have been thermally altered. This is important because there are certain temperature thresholds for the generation of oil and gas (Staplin, 1977; Dow, 1977; Batten 1980; Batten 1980, 1981; Fig. 1).

Transmitted light microscopy of dispersed organic matter is a relatively cheap, quick and, despite its subjectivity, surprisingly accurate method of determining maturation levels and recognising hydrocarbon source facies. It is, therefore, an important tool for assessing petroleum potential in sedimentary basins. For the most reliable conclusions, data from such analyses and their implications should be compared and correlated routinely with the results of vitrinite reflectance, fluorescence and geochemical studies on the same sections.

\section{ACKNOWLEDGEMENTS}

This paper is based on a talk given at the Annual General Meeting of the British Micropalaeontological Society, November, 18th, 1981. I am grateful to the British Petroleum Company Ltd for permission to publish photographs of preparations of their samples, and to the Institute of Geological Sciences for access to borehole material. Michael Fisher (British National Oil Corporation) provided helpful comments on the manuscipt.

\section{REFERENCES}

Allen, P. 1959. The Wealden environment: Anglo-Paris basin. Phil. Trans. R. Soc., London, Series B, 242, 283-346.

Allen, P. 1967. Origin of the Hastings facies in northwestern Europe. Proc. Geol. Ass., London, 78, 27105.

Allen, P. 1975. Wealden of the Weald: a new model. Proc. Geol. Ass., London, 86, 389-437.

Allen, P. 1981. Pursuit of Wealden models. J. geol. Soc. London, 138, 375-405.

Batten, D.J. 1968. Probable dispersed spores of Cretaceous Equisetites. Palaeontology, London, 11, 633-642.

Batten, D.J. 1969. Some British Wealden megaspores and their facies distribution. Palaeontology, London, 12. 333-350.

Batten, D.J. 1973a. Use of palynologic assemblagetypes in Wealden correlation.Palaeontology, London, 16, 1-40.

Batten, D.J. 1973b. Palynology of Early Cretaceous soil beds and associated strata. Palaeontology, London, 16, $399-424$.

Batten, D.J. 1974. Wealden palaeoecology from the distribution of plant fossils. Proc. Geol. Ass., London, 85, 433-458.

Batten, D.J. 1978. Early Cretaceous to Middle Jurassic miospores and palynofacies of the northwest European continental shelf. In Thusu, B. (Ed.), Distribution of biostratigraphically diagnostic dinoflagellate cysts and miospores from the northwest European continental shelf and adjacent areas. Continental Shelf Inst. Publ., 100, 97-101.

Batten, D.J. 1980. Use of transmitted light microscopy of sedimentary organic matter for evaluation of hydrocarbon source potential. IV Int. Palynol. Conf., Lucknow (1976-77), 2, 589-594.

Batten, D.J. 1981. Palynofacies, organic maturation and source potential for petroleum. In Brooks, J. (Ed.), Organic maturation studies and fossil fuel exploration, pp. 201-223, Academic Press, London. 
Batten, D.J. in press. Palynofacies and salinity in the Purbeck and Wealden of southern England. George Allen \& Unwin, London.

Batten, D.J. \& Eaton, G.L. 1980. Dinoflagellates and salinity variations in the Wealden (Lower Cretaceous) of southern England. Abstr. V Int. Palynol. Conf., p. 32.

Batten, D.J. \& Morrison, L. in press. Methods of palynological preparation for palaeoenvironmental, source potential and organic maturation studies. $\mathrm{Publ}$. NPD, Stavanger.

Bostick, N. H. 1971. Thermal alteration of clastic organic particles as an indicator of contact and burial metamorphism in sedimentary rocks. Geoscience and Man, 3, 83-92.

Combaz, A. 1964. Les palynofaciès. Revue Micro paléont., Paris, 7, 205-218.

Cope, M.J. 1981. Products of natural burning as a component of the dispersed organic matter of sedimentary rocks. In Brooks, J. (Ed), Organic maturation studies and fossil fuel exploration, pp. 89-109, Academic Press, London.

Denison, C. \& Fowler, R.M. 1980. Palynological identification of facies in a deltaic environment. Publ. $N P F, 1-22$.

Dow, W.G. 1977. Kerogen studies and geological interpretations. J. Geochem. Explor., 7, 79-99.

Habib, D. 1979. Sedimentary origin of North Atlantic Cretaceous palynofacies. In Talwani, M., Hay, W. \& Ryan, W. B. F. (Eds.), Deep drilling results in the Atlantic Ocean: continental margins and palaeoenvironment, Maurice Ewing Series 3, American Geophysical Union, pp. 420-437.

Hancock, N. J. \& Fisher, M. J. 1981. Middle Jurassic North Sea deltas with particular reference to Yorkshire. In Illing, L. V. \& Hobson, G. D. (Eds.), Petroleum geology of the continental shelf of North-West Europe, pp. 186-195, Institute of Petroleum, London.

Harris, T.M. 1958. Forest fire in the Mesozoic. J. Ecol., London, 46, 447-453.

Hughes, N.F. \& Moody-Stuart. J.C. 1967. Palynological facies and correlation in the English Wealden. Rev. Palaeobot. Palynol., Amsterdam, 1, 259-268.
Muller, J. 1959. Palynology of Recent Orinoco delta and shelf sediments. Micropaleontology, New York, $5,1-32$.

Parry, C.C., Whitley, P.K. J. \& Simpson, R.D.H. 1981. Integration of palynological and sedimentological methods in facies analysis of the Brent Formation. In Illing, L.V. \& Hobson, G.D. (Eds.), Petroleum geology of the continental shelf of North-West Europe, pp. 205-215, Institute of Petroleum, London.

Scott, A.C. \& Collinson, M.E. 1978. Organic sedimentary particles: results from scanning electron microscope studies of fragmentary plant material. In Whalley, W. B. (Ed.), Scanning electron microscopy in the study of sediments, pp. 137-167, Geo Abstracts, Norwich.

Stach, E., Mackowsky, M.-Th., Teichmüller, M. et al. 1975. Stach's textbook of coal petrology, translation and English revision by Murchison, D.G.. Taylor, G.H. \& Zierke, F., xii + 428 pp., Gebrüder Borntraeger, Berlin.

Staplin, F.L. 1977. Interpretation of thermal history from color of particulate organic matter - a review. Palynol., Austin, 1, 9-18.

Stewart, D.J. 1981 a. A meander belt sandstone from the Lower Cretaceous Wealden Group of southern England. Sedimentology, 28, 1-20.

Stewart, D.J. 1981b. A field guide to the Wealden Group of the Hastings area and the Isle of Wight. In Elliot, T. (Ed.), Field guides to modern and ancient fluvial systems in Britain and Spain. Publ. Internat. Fluvial Cont., Univ. Keele, 3.1-3.31.

Tissot, B.P. \& Welte, D.H 1978. Petroleum formation and occurrence, xviii + 538 pp., Springer-Verlag, Berlin.

Tyson, R.V., Wilson, R.C.L. \& Downie, C. 1979. A stratified water column environmental model for the type Kimmeridge Clay. Nature, Lond., 277, 377380 . 